\title{
MODELLING OF GRAIN BOUNDARY RESISTANCE IN THIN FILMS OF LANTHANUM MANGANITES
}

\author{
V. Petrauskas and E.E. Tornau \\ Semiconductor Physics Institute, A. Goštauto 11, LT-01108 Vilnius, Lithuania \\ E-mail: et@pfi.lt
}

Received 12 December 2005

\begin{abstract}
We present two phenomenological models to calculate the grain boundary resistance in polycrystalline and two-phase lanthanum manganites. Using the first model we demonstrate that it is not the total magnetization, but rather the difference in magnetization of neighboring magnetic grains that plays the most important role in temperature dependences of resistance and magnetoresistance of doped polycrystalline lanthanum manganites with grain boundaries. Our calculations show that, in order to obtain the maximum in temperature dependence of resistance at $T_{\mathrm{m}}$, grain boundary layers have to be, at least, weakly ferromagnetic. Increase of the ferromagneticity of these layers leads to decrease of resistance, increase of $T_{\mathrm{m}}$, and decrease of the difference between $T_{\mathrm{m}}$ and Curie temperature $T_{\mathrm{C}}$. Increase in the number of grain boundaries also leads to increase of resistance, but does not affect the value of $T_{\mathrm{m}}$. The second model is devoted to relation of resistivity and magnetization in two-phase thin films of lanthanum manganites. Every plane is asumed to be a mixture of two ferromagnetic phases with different magnetizations and concentrations. Thin film, represented as the system of such planes, is reduced to a circuit of resistances connected in parallel. The grain boundary resistivity is expressed as the difference in magnetization of phases. For such a system we have found that the peak of resistivity $T_{\mathrm{m}}$ decreases and shifts towards higher values of temperature with increase of film thickness, the result which qualitatively agrees with experimental data.
\end{abstract}

Keywords: colossal magnetoresistance, thin lanthanum manganite films, ferromagnetism

PACS: 72.25.Mk, 73.40.Gk, 75.47.Lx

\section{Introduction}

Doped lanthanum manganites exhibiting colossal magnetoresistance (MR) effect are studied very intensively in recent years due to a great number of various practical applications which this property can provide. Thin films of these compounds of rather different quality are needed for the applications. For example, single crystals or epitaxial thin films of popular lanthanum manganite $\mathrm{La}_{1-x} \mathrm{Sr}_{x} \mathrm{MnO}_{3}$ exhibit the highest magnetoresistance only close to the resistivity maximum (around 200-250 K), while the polycrystalline samples show high values of the magnetoresistance in a long interval of temperatures including room temperature.

Temperature dependence of resistance $R(T)$ might be at least one of possible indicators of the sample quality. It is well known that in doped manganites, such as e. g. $\mathrm{La}_{1-x} \mathrm{Ca}_{x} \mathrm{MnO}_{3}$ (LCMO) with doping $x$ around $0.2-0.4, R(T)$ exhibits maximum at metal-insulator transition temperature $T_{\mathrm{m}}$, which for the single crystals coincide with (or is rather close to) ferromagnetic to paramagnetic phase transition (Curie) temperature $T_{\mathrm{C}}$. Polycrystalline samples of poor quality and very thin films have a lot of similar properties [1]. High values of resistance, high field hysteresis, low values of temperature $T_{\mathrm{m}}$, notable difference $T_{\mathrm{C}}-T_{\mathrm{m}}$, and high values of MR down to low temperature are observed for both of them, evidencing much higher degree of system's disorder in comparison with single crystals or epitaxial films. This disorder is related to imperfections of fabrication of polycrystalline samples and substrate strain fields, occurring due to mismatch of substrate and manganite lattice constants, for very thin films. In comparison with very thin films, thicker films (especially the epitaxial ones) possess the electric and magnetic properties much more resembling those of the single crystals. Epitaxial films are characterized by higher values of $T_{\mathrm{m}}$ and much lower values of resistivity at $T_{\mathrm{m}}$. Their MR is maximum near $T_{\mathrm{m}}$ (which for this case is rather close to $T_{\mathrm{C}}$ ), but very low at low temperature [2].

Broad maximum of resistivity (low $T_{\mathrm{m}}$ ) below $T_{\mathrm{C}}$ in polycrystalline and thin films systems is sometimes explained by bad connectivity, grain size effects, or in- 
crease of grain boundaries and correspondingly barriers for carriers tunnelling between ferromagnetic (FM) and paramagnetic (PM) grains. In Ref. [2] it was demonstrated that conduction is achieved through less resistive channels connected in parallel and is dominated by connectivity between grains, but not grain size effects. On the contrary, the analysis [3] of $\mathrm{La}_{0.67} \mathrm{Sr}_{0.33} \mathrm{MnO}_{3}$ grains with sizes between $20 \mathrm{~nm}$ and $10 \mu \mathrm{m}$ have shown that the so-called high field MR progressively rises when reducing the grain size and the reason of this effect is the existence of non-collinear magnetic surface layer on the surface of the smallest grains. In Ref. [4] it was shown that the peak at $T_{\mathrm{m}}$ might be due to intrinsic resistance (high quality single crystals or epitaxial films, low values of resistance, high values of $T_{\mathrm{m}}$ ) as well as extrinsic resistance (samples with grain boundaries, high values of resistances, low values of $T_{\mathrm{m}}$ ). The competition between two magnetoresistances, observed in phase separated lanthanum manganites - intrinsic colossal MR and extrinsic tunnelling MR - was also analysed in Ref. [5] by the tunnelling percolation model by mapping it to random resistor network model, and qualitative explanation of magnetotransport in terms of grain size, grain boundaries, and intergranular connectivity, was obtained.

Here we present two simple models explaining the behaviour of temperature dependences of resistance and magnetoresistance in doped manganites systems with grain boundaries (GB). First model could be applied to polycrystalline bulk compounds of poor quality (i. e. with considerable number of GB), the second one - to thin manganite films. Both models could be applied to such compounds in which the total resistance is actually determined by GB (tunnelling or intergrain) resistance, and intrinsic intragrain resistance is much less than the GB resistance. In defining the tunnelling resistance between two grains, we exploit some ideas of Gross et al. [4]. For the first model we artificially introduce additional PM planes in otherwise FM film, thus simulating the occurrence of the GB layers. Thus we obtain the difference in neighbouring grains magnetization which is the key parameter of our model.

\section{Models for grain boundary resistance}

One of possible scenarios of the carrier transport in doped lanthanum manganites with GB considers the tunnelling of carriers through the GB. Very nice illustration of this effect is proposed by Gross et al. [4]. There are two peaks in temperature dependence of resistance obtained with their samples: low temperature peak of higher resistance is associated with artificially fabricated GB, and lower resistance peak with higher $T_{\mathrm{m}}$ is characteristic to intrinsic MR properties of the epitaxial thin film.

The explanation of this effect given in Ref. [4] might be summarized as follows. The system consists of FM grains separated by PM GB layers. Above $T_{\mathrm{C}}$ to the FM phase the work functions $\Phi_{\mathrm{PM}}$ of two neighbouring islands are more or less equal, because they are both PM. Below $T_{\mathrm{C}}$ the separation into FM grains and PM GB layers takes place, and work function of the FM grain increases with respect to that of the neighbouring PM grain, $\Delta \Phi=\Phi_{\mathrm{FM}}-\Phi_{\mathrm{PM}}$. To keep the system's Fermi level intact, this leads to the band bending in the PM GB and, consequently, to occurrence of a charge depleted zone there. Using support of some ideas of [6] and their own experiments, Gross et al. demonstrate [4] that $\Delta \Phi$ is proportional to a magnetization squared. However, and it should be emphasized here, the magnetization in their work has not the meaning of total magnetization as in the works of Furukawa [6] and Viret et al. [7]. To be precise, $\Delta \Phi=\sum_{i} \Delta M_{i}^{2}$, where $\Delta M_{i}=M_{i+1}-M_{i}$ is the difference in magnetization between $i$ th and $(i+1)$ th grain. The difference in work function occurs if "ferromagneticity" (e.g. $T_{\mathrm{C}}$ ) of neighbouring grains is different, especially if one is FM and another PM.

The size of depleted zone at the GB has been shown [4] to be $t \sim \Delta \Phi^{1 / 2}$. On the other hand, using WKB approximation the tunnelling resistance through rectangular barrier of height $\Delta \Phi$ and thickness $t$ has been estimated [8] as $R=4 \pi^{2} \hbar t \exp (2 k t) /\left(k e^{2}\right)$, where $k=\left(2 m \Delta \Phi / \hbar^{2}\right)^{1 / 2}, e$ and $m$ are elementary charge and effective mass of a carrier. Consequently, one obtains $R \sim \exp (\Delta \Phi)$, and resistance crucially depends on a difference in magnetization at the GB.

It should be noted that here we assume that extrinsic GB resistance is much larger than the intrinsic resistance inside the FM grains. For not perfect samples the GB resistance possibly plays a crucial role and defines if not the form then at least the magnitude and location of resistance maxima $T_{\mathrm{m}}$.

\subsection{Model 1: Polycrystalline system}

Here we simulate the magnetization of a polycrystalline sample with a simple cubic lattice $(z=6)$ and artificially introduce GB. The interaction of the mean field and the external field $H$ with the mean magnetic 


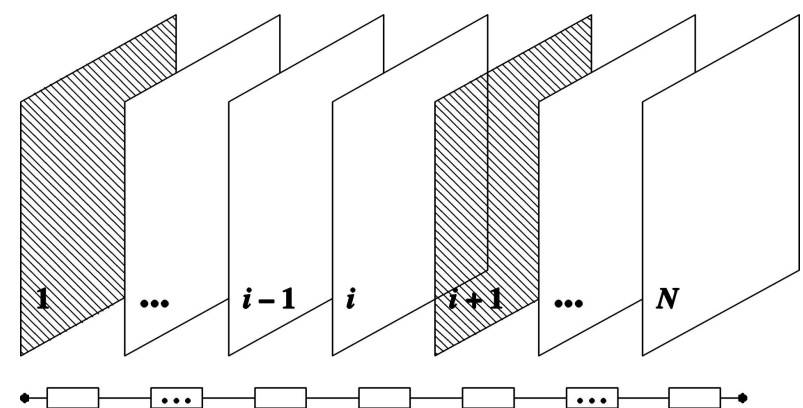

Fig. 1. Schematic representation of $N$ magnetic planes as a onedimensional system of $N$ resistances connected in series. Here the planes 1 and $N$ are intentionally shown shaded to emphasize that they create GB and therefore their FM properties (described by interaction constant $J_{1}$ ) are different from those of other planes which are described by constant $J$.

moment $M_{i}=g \mu_{\mathrm{B}}\left\langle s_{i}\right\rangle$ in $i$ th plane can be described by the following equation:

$\left\langle s_{i}\right\rangle=s B\left\{\frac{s\left[J\left(4\left\langle s_{i}\right\rangle+\left\langle s_{i+1}\right\rangle+\left\langle s_{i-1}\right\rangle\right)+g \mu_{\mathrm{B}} H\right]}{k_{\mathrm{B}} T}\right\}$,

where $s$ is the spin moment, $\left\langle s_{i}\right\rangle$ is its thermally averaged value in $i$ th plane, $J$ is the exchange constant of interactions between spins. Here $B\{\ldots\}$ is the Brillouin function, $k_{\mathrm{B}}$ and $g$ are Boltzmann and Lande factors, $\mu_{\mathrm{B}}$ is Bohr magneton, and $T$ is the temperature. In the following we assume $s=s\left(\mathrm{Mn}^{3+}\right)=2$. The solution for magnetization in the $i$ th plane is related to the magnetizations in the neighbouring planes. Thus, to obtain total magnetization of the system of thickness $d=N a$, we have to solve the system of equations (1) for $N$ planes, where $a=a_{i}-a_{i \pm 1}$ is the lattice parameter. At $H=0$ the system undergoes FM phase

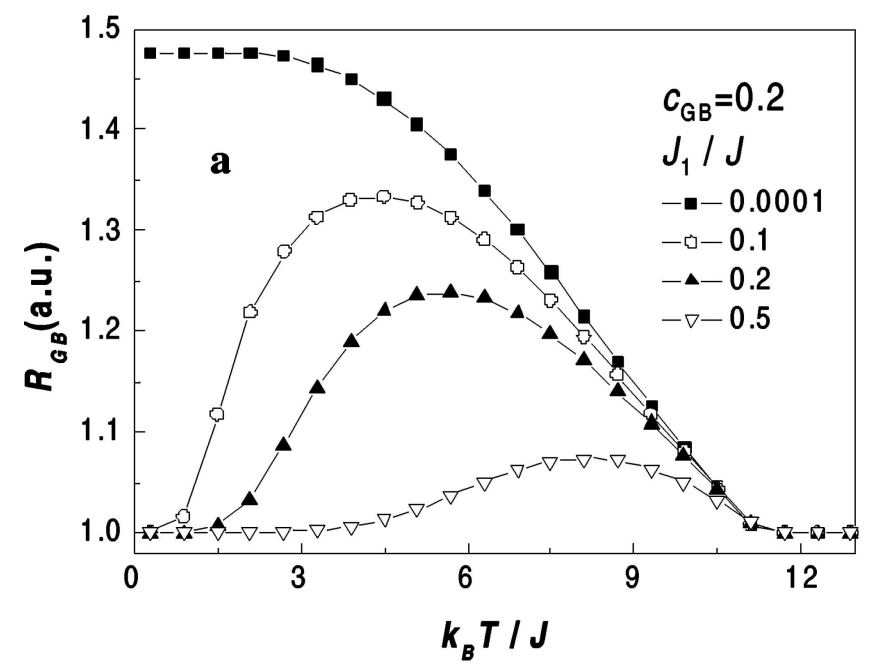

(a) transition at $k_{\mathrm{B}} T_{\mathrm{C}}=s(s+1) z J / 3=12 J$ [9]. The tunnelling current is assumed to flow perpendicular to the film planes. Thus if we assume each plane to be a separate resistance we end up with a one-dimensional system of $N$ resistances connected in series (see Fig. 1).

Now we start to artificially introduce PM planes in FM thin film, imitating the occurrence of the GB layers, and calculate the difference in magnetization of neighbouring planes $\Delta M=\left(\sum_{i} \Delta M_{i}^{2}\right) / N$. This is the key parameter characterizing our tunnelling resistance function which we define as $R_{\mathrm{GB}}=R_{0} \exp (c \Delta M)$. Here $R_{0}$ is the resistance part which does not depend on GB (comprising resistance in the grains and polaronic activated resistance dominating at $T>T_{\mathrm{C}}$ ) and $c$ is constant. Here we are seeking for just qualitative description and therefore for simplicity take $R_{0}=c=1$ and define $R_{\mathrm{GB}}$ as "GB resistance" (or $R_{\mathrm{GB}^{-}}$) function. This function starts to deviate from unity below $T_{\mathrm{C}}$.

Insertion of purely PM planes $\left(J=J_{1}=0\right.$ within these planes and for interaction with the spins in both neighbouring planes) leads to saturation of $R_{\mathrm{GB}}$ at low temperatures. However, if the introduced planes demonstrate at least weak FM behaviour (say, $J_{1}=$ $0.1 J$ ), the $R$-function has the peak at $T_{\mathrm{m}}$, and this peak moves to higher values of temperature towards $T_{\mathrm{C}}$ with increase of $J_{1}$ as shown in Fig. 2(a). Moreover, the GB resistance considerably decreases with decrease of $T_{\mathrm{C}}-T_{\mathrm{m}}$. Thus, to obtain the peak of resistance, the GB layer has to be, at least, weakly FM, and the best quality samples (low resistance and $T_{\mathrm{m}}$ close to $T_{\mathrm{C}}$ ) are those which have $J_{1} \rightarrow J$ or correspondingly $T_{\mathrm{C}}$ of inserted layer $\rightarrow T_{\mathrm{C}}$, i. e. epitaxial films without GB. According to this model, the polycrystalline samples

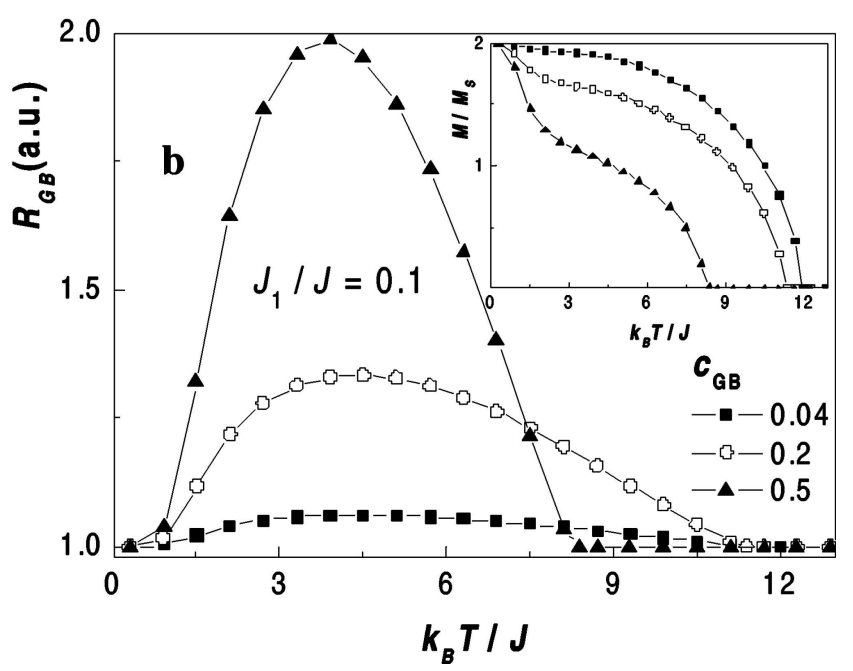

(b)

Fig. 2. Temperature dependence of $R_{\mathrm{GB}}$ (a) for concentration of inserted planes $c_{\mathrm{GB}}=0.2$ and different values of $J_{1}$ and (b) for $J_{1}=0.1$ and different number of inserted planes. Inset: temperature dependence of total magnetization for $J_{1}=0.1$ and different $c_{\mathrm{GB}}$. 


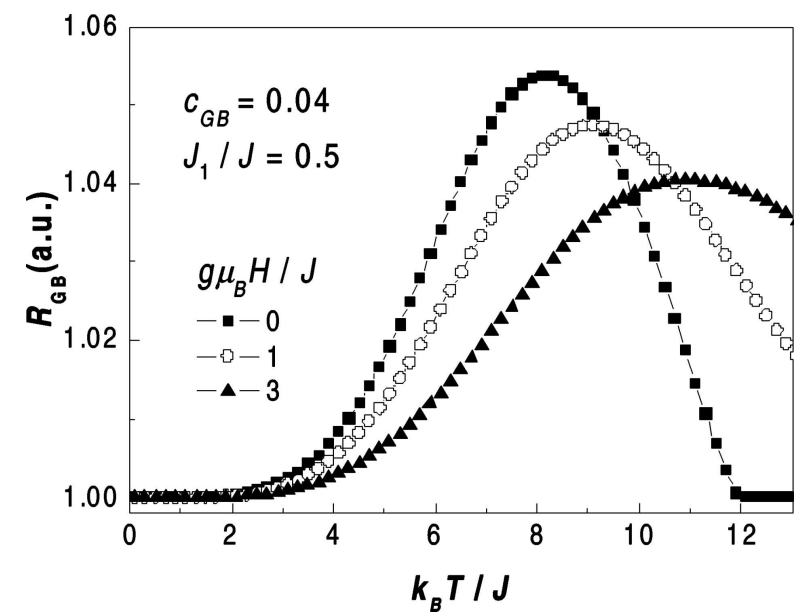

Fig. 3. Temperature dependence of $R_{\mathrm{GB}}$ for different values of external magnetic field and $c_{\mathrm{GB}}=0.04$.

have the GB which are due to inserted layers with poor "ferromagneticity". The peak at $T_{\mathrm{m}}$ is formed due to increase of magnetization in normal FM planes below $T_{\mathrm{C}}$ accompanied by induction of FM order in neighbouring inserted weakly FM $\left(J_{1}<J\right)$ planes at further decrease of temperature and decrease of magnetization difference $M_{\mathrm{FM}}-M_{\mathrm{FM} \text { (inserted) }}$ below $T_{\mathrm{m}}$.

The $R_{\mathrm{GB}}$-function and magnetization temperature dependences for different number of inserted weakly FM planes (or concentration of GB planes $c_{\mathrm{GB}}$ ) are presented in Fig. 2(b). It is seen that resistance increases, but the value of $T_{\mathrm{m}}$ changes very weakly with increase of $c_{\mathrm{GB}}$, the parameter, actually characterizing the order of the polycrystallinity of the system. The $R_{\mathrm{GB}}$-function also decreases with increase of external magnetic field $H$ in accordance with experimental findings for resistivity of colossal MR materials (see

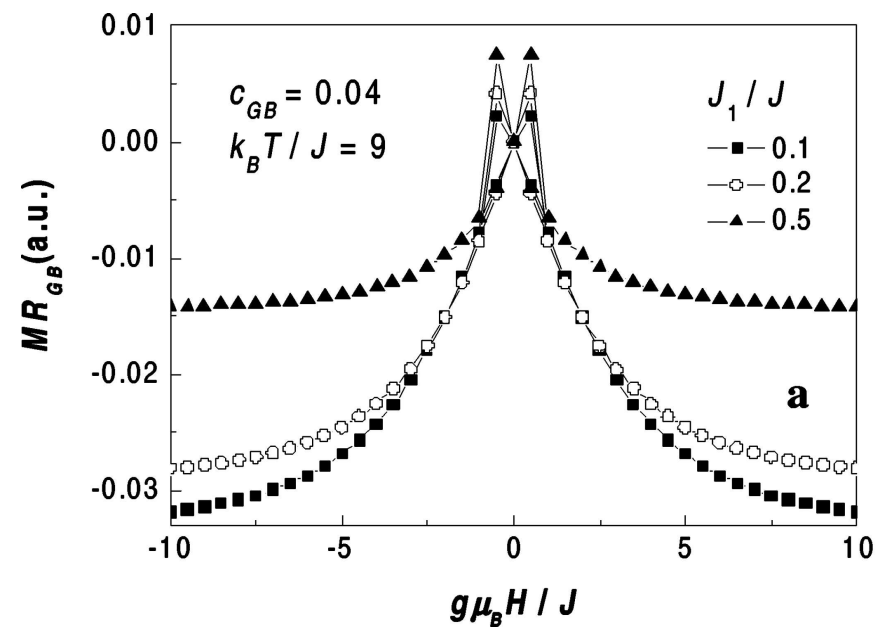

(a)
Fig. 3). However, differently from the experiments, at higher temperature values we observe the intersection of tails of $R_{\mathrm{GB}}$-function for different values of $H$.

In Fig. 4 we presented the calculated magnetoresistance function $M R_{\mathrm{GB}}=\left(R_{\mathrm{GB}}(H)-R_{\mathrm{GB}}(0)\right) / R_{\mathrm{GB}}(0)$ for different values of $J_{1}$ and $c_{\mathrm{GB}}$. The effect of hysteresis is seen which is always present for polycrystalline samples of $(\mathrm{La} \text { or } \mathrm{Pr})_{1-x}(\mathrm{Sr} \text { or } \mathrm{Ca})_{x} \mathrm{MnO}_{3}$ (see e. g. $[1,10])$. Since the field is directed along or opposite the magnetization direction, the value of coercive field depends rather weakly on variation of $J_{1}$ and GB concentration, as could be seen also from $M(H)$ dependence given in inset of Fig. 4(b).

\subsection{Model 2: Two-phase film. Resistances connected in parallel}

The simplest model for magnetization of a twophase system is the model of an alloy [8]. In this model the spin in any site of the lattice experiences the same mean field which is proportional to the concentration of both ingredients. However this model cannot work for thin films, irrespective of how "badly" they have been fabricated. Thin film, most likely, has to be characterized by more strained phase closer to the substrate and "strain-relaxed" phase (with magnetic properties closer to those of the bulk system) near the top of the film. Obviously, in this case the composition of the first phase $c_{1}$ has to decrease and the composition of the second phase $c_{2}=1-c_{1}$ has to increase with increase of film thickness $d$. We assume that this dependence can be nicely described by the Boltzmann function $c_{2}=1 /\left(1+\exp \left[-k\left(d-d_{0}\right) / a\right]\right)$, where $d_{0}$ is the thickness at which the compositions of phases are

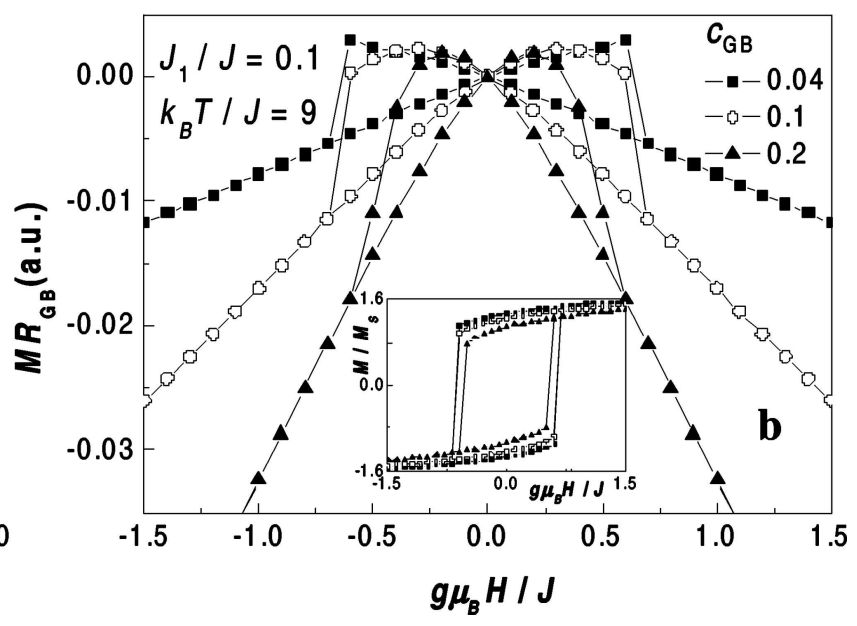

(b)

Fig. 4. Magnetoresistance function $M R_{\mathrm{GB}}=\left(R_{\mathrm{GB}}(H)-R_{\mathrm{GB}}(0)\right) / R_{\mathrm{GB}}(0)$ at $k_{\mathrm{B}} T / J=9$ for (a) different $J_{1}$ at $c_{\mathrm{GB}}=0.04$ and (b) for different $c_{\mathrm{GB}}$ at $J_{1} / J=0.1$. 
equal $\left(c_{1}\left(d_{0}\right)=c_{2}\left(d_{0}\right)=0.5\right)$ and $k$ is the parameter, in some way, characterizing the fabrication (or phase separation) conditions: high values of $k$ correspond to abruptly separated phases, while low values indicate high degree of mixing in the system. Here $a=a_{i}-a_{i \pm 1}$ is the lattice parameter and $i$ is the plane index. In such a system for simple cubic lattice the interaction of the mean fields and the external magnetic field $H$ with the mean magnetic moments $M_{1 i}=g \mu_{\mathrm{B}}\left\langle s_{1 i}\right\rangle$ and $M_{2 i}=g \mu_{\mathrm{B}}\left\langle s_{2 i}\right\rangle$ of both phases in $i$ th plane can be described by the following equations:

$$
\begin{aligned}
\left\langle s_{1 i}\right\rangle= & s_{1} B\left\{s _ { 1 } \left[J_{11} c_{1}\left(4\left\langle s_{1 i}\right\rangle+\left\langle s_{1 i+1}\right\rangle+\left\langle s_{1 i-1}\right\rangle\right)\right.\right. \\
& +J_{12} c_{2}\left(4\left\langle s_{2 i}\right\rangle+\left\langle s_{2 i+1}\right\rangle+\left\langle s_{2 i-1}\right\rangle\right) \\
& \left.\left.+g \mu_{\mathrm{B}} H\right] / k_{\mathrm{B}} T\right\}, \\
\left\langle s_{2 i}\right\rangle= & s_{2} B\left\{s _ { 2 } \left[J_{21} c_{1}\left(4\left\langle s_{1 i}\right\rangle+\left\langle s_{1 i+1}\right\rangle+\left\langle s_{1 i-1}\right\rangle\right)\right.\right. \\
& +J_{22} c_{2}\left(4\left\langle s_{2 i}\right\rangle+\left\langle s_{2 i+1}\right\rangle+\left\langle s_{2 i-1}\right\rangle\right) \\
& \left.\left.+g \mu_{\mathrm{B}} H\right] /\left(k_{\mathrm{B}} T\right)\right\},
\end{aligned}
$$

where $s_{1}$ and $s_{2}$ are spin moments of both phases $\left(s_{1}=s_{2}=s\left(\mathrm{Mn}^{3+}\right)=2\right),\left\langle s_{1 i}\right\rangle$ and $\left\langle s_{2 i}\right\rangle$ are their thermally averaged values in $i$ th plane, $J_{11}, J_{22}$, and $J_{12}=J_{21}$ are the exchange constants of interactions between spins of the first phase, between spins of the second phase, and between spins of the first and second phase, respectively. The solution for magnetization in the $i$ th plane of components $M_{1 i}$ and $M_{2 i}$ and plane magnetization $M_{i}=M_{1 i}+M_{2 i}$ is related to the magnetizations in the neighbouring planes. Thus, to obtain total magnetization of the film of thickness $d=N a=d_{0}-(a / k) \ln \left[\left(1-c_{2}\right) / c_{2}\right]$, we have to solve the system of equations (2) for $N$ planes.

In this model the given planes are arranged parallelly to the substrate and the current is assumed to flow parallelly to the planes. Thus, if we consider, as in the previous example, one plane as one resistance, we have the system of resistances connected in parallel as in Fig. 5. Accepting such a viewpoint we also take into account that the resistances which are closer to the substrate (low $d$, prevailing in the phase 1 ) are higher-ohmic than those of the top layers (high $d$, prevailing in the phase 2). Thus in our model we take two phases: FM phase 2 dominating for thick films and higher planes and strained weakly FM phase 1 dominating closer to the substrate. This approach is consistent with results of many studies, in particular Ref. [11], which moti-

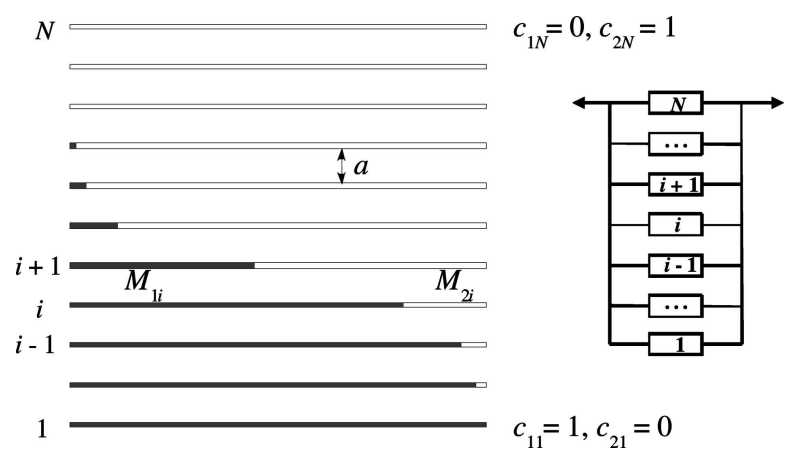

Fig. 5. Schematic representation of $N$ magnetic planes of a thin film as $N$ resistances connected in parallel. White (black) shading of planes indicates the concentration of the second (first) phase in the plane according to formulae $c_{2}=1 /\left(1+\exp \left[-k\left(d-d_{0}\right) / a\right]\right)$ and $c_{1}=1-c_{2}$. The concentrations of both phases in the planes 1 and $N$ are shown for clarity.

vate the suppression of conductivity in very thin nanometric films not by mismatch of substrate and film lattices (because they are almost matching in their experiments), but rather by charge localization near the interface which leads to a weakening of FM interactions and a decrease of Curie temperature. In our case this is related to the phase 1 , i. e. $J_{11}$ is expected to be less or even much less than $J_{22}$.

For each plane (resistance) $i$ we obtain magnetization of both these phases $M_{1 i}$ and $M_{2 i}$ and calculate their corresponding weights from Boltzmann function. The parameter characterizing difference of the magnetization at the GB junctions of the $i$ th plane has to be proportional to their difference multiplied by concentration of the minority phase, $\left(M_{2 i}-M_{1 i}\right) c_{1 i}$. As in Ref. [4], we take the magnetization difference squared. Thus finally we obtain GB resistance of $i$ th plane in the form

$$
R_{\mathrm{GB} i}=R_{0 i} \exp \left[n_{\mathrm{GB} i}\left(M_{2 i}-M_{1 i}\right)^{2} c_{1 i}\right],
$$

and total conductance of a thin film is $R_{\mathrm{GB}}^{-1}=\sum_{i} 1 / R_{\mathrm{GB} i}$. Here $n_{\mathrm{GB}}$ is the parameter characterizing the number of GB (or how densely the minority phase is distributed in the majority phase) in $i$ th plane. In the following we take all $R_{0 i}=n_{\mathrm{GB} i}=1$ for simplicity. In our model the highest resistances are near the substrate, where $c_{1 i}>c_{2 i}$ and the lowest for $c_{1 i} \rightarrow 0$, i.e. near the top of the sample. In order to obtain the total GB resistance we have to sum GB resistances of each plane from 1 to $N$. Actually only the planes for $d \geq d_{0}$ $\left(c_{2} \geq 0.5\right)$ have to be considered, because, when connected in parallel, high ohmic resistances near the substrate give very small contribution to the total resistance [11]. On the other hand, omitting the resistances with $c_{2} \leq 0.5$ should be justified by the fact that this is 


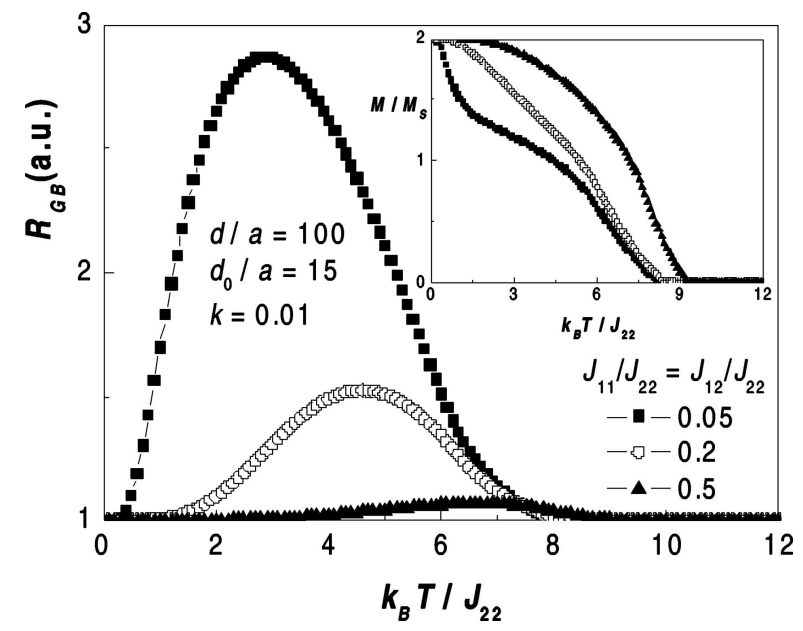

Fig. 6. Temperature dependence of $R_{\mathrm{GB}}$ and magnetization (inset) for different values of $J_{11}=J_{12}$.

exactly the threshold of the percolation of the phase 2 in phase 1 on square lattice. It is noteworthy that we can obtain the maximum of $R_{\mathrm{GB}}(T)$ function summing over all planes also, but the omission of high ohmic resistances leads to variation of $T_{\mathrm{m}}$ with $d$ in larger limits in accordance with experimental results.

Temperature dependences of GB resistivity are demonstrated in Fig. 6 for $d=100 a$ and different values of $J_{11}=J_{12}$. The Boltzmann function parameters are $d_{0}=15 a$ and $k=0.01$, i.e. the prevailing of the phase 1 is only in 15 planes nearest to the substrate, but the saturation of phase 2 with distance is rather slow $\left(c_{2 i} \sim 1\right.$ is for $\left.N=d / a>500\right)$. The peak moves towards higher values of temperature with increase of ferromagneticity of minority phase as in the previous model. Temperature dependences of magnetization (inset) also show induction of magnetization of phase 2 in phase 1 below $T_{\mathrm{C}}$, which is especially pronounced for the sample with low $J_{1}=J_{11} / J_{22}=J_{12} / J_{22}$.

The most interesting effect, resistivity dependence on sample thickness is found in most experiments on thin films of lanthanum manganites (see e. g. [11, 12]). Our model can also describe this effect as shown in Fig. 7. For $J_{1}=0.05$, the ratio $t=T_{\mathrm{m}}(d=$ $16 a) / T_{\mathrm{m}}(d=400 a)=0.62$. Here $T_{\mathrm{m}}$ at $d=400 a$ might be taken as $T_{\mathrm{m}}$ of a bulk compound. This ratio slightly increases with increase of $J_{1}$, e.g. $t=0.69$ for $J_{1}=0.2$ and $t=0.77$ for $J_{1}=0.5$ (see Fig. 8). For epitaxial two-phase $\mathrm{La}_{0.83} \mathrm{Sr}_{0.17} \mathrm{MnO}_{3}$ samples with thickness ranging from 4 to $140 \mathrm{~nm}$ the ratio $t=T_{\mathrm{m}}(d=4 \mathrm{~nm}) / T_{\mathrm{m}}(d=140 \mathrm{~nm})$ is also around 0.7 [12]. In our model this ratio also slightly depends on the parameters of the Boltzmann function. For abrupt separation of phases and fast saturation of

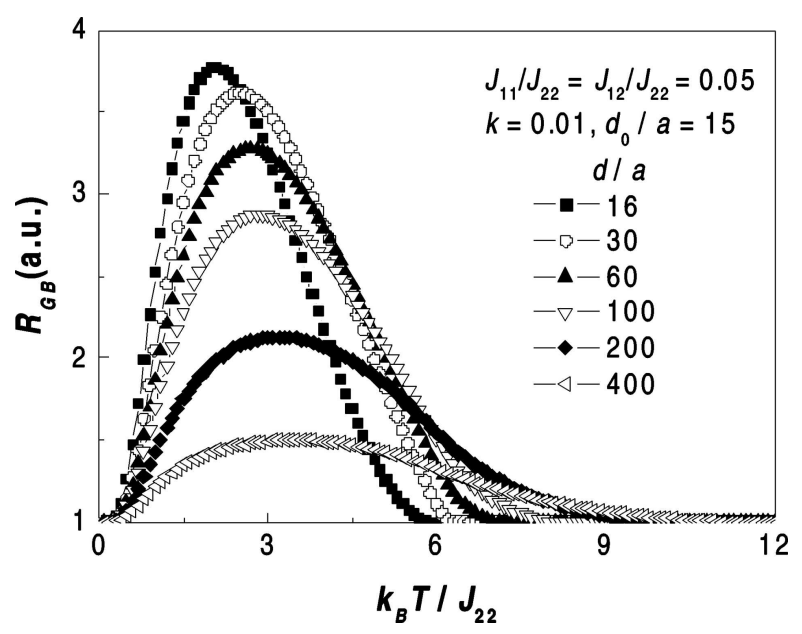

Fig. 7. Temperature dependence of $R_{\mathrm{GB}}$ for different values of film thickness.

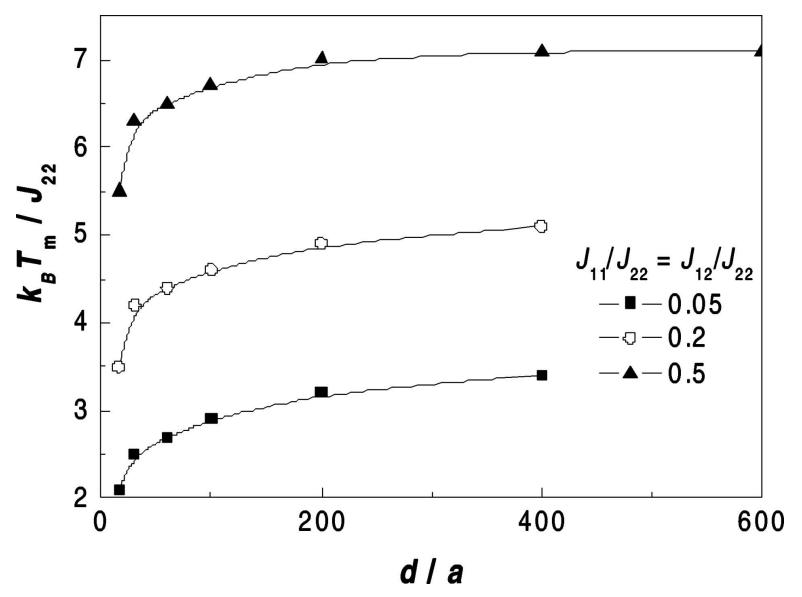

Fig. 8. Temperature of $R_{\mathrm{GB}}$ maximum as a function of film thickness at different values of $J_{11}=J_{12}$.

phase 2 (much larger $k$ ) the thickness effect in $t$ is quite weak $(t \geq 0.9)$.

\section{Conclusions}

We present two models to calculate the resistance in polycrystalline and thin films of lanthanum manganites. Studying the tunnelling through the artificially introduced grain boundaries resistance $R_{\mathrm{GB}}$, we use the relation between resistance and difference in magnetization of local grains and grain boundary layers. Using the one-dimensional model, which could be applied for polycrystalline lanthanum manganite, we have shown that grain boundary layers have to be at least weakly ferromagnetic in order to obtain the peak of resistance at $T_{\mathrm{m}}$ in its temperature dependence. With increase of ferromagneticity (Curie temperature) of grain boundary layer the peak at $T_{\mathrm{m}}$ decreases and moves towards higher values of temperature. The increase of concen- 
tration of grain boundary layers also leads to reduction of the peak, but almost does not change the $T_{\mathrm{m}}$ value. We obtain the hysteresis in magnetic field dependences of magnetoresistance when the field is parallel to magnetization.

Good qualitative agreement for decrease and shift of $T_{\mathrm{m}}$ with increase of film thickness is obtained for the second model devoted to calculation of resistivity of thin films consisting of two phases. We assume that each plane of the film corresponds to one resistance. Then total resistivity for current flowing parallel to the planes is calculated as for resistances connected in parallel. The resistance for each plane is obtained in terms of plane magnetization which we obtain by calculating the magnetization of both phases and their corresponding weights.

\section{Acknowledgements}

We thank Lithuanian State Science and Studies Foundation (project Nr. T-19/05-01) and EC project PRAMA for financial support. Discussions with S. Balevičius, N. Žurauskienė, and S. Lapinskas are gratefully acknowledged.

\section{References}

[1] M.G. Blamire, B.-S. Teo, J.H. Durrell, N.D. Mathur, Z.H. Barber, J.L. McManus Driscoll, L.F. Cohen, and J.E. Evetts, Strain-induced time-dependent magnetic disorder in ultra-thin $\mathrm{La}_{0.7} \mathrm{Sr}_{0.3} \mathrm{MnO}_{3}$, J. Magn. Magn. Mater. 191, 359-367 (1999).

[2] A. de Andres, M. Garcia-Hernandez, and J.L. Martinez, Conduction channels and magnetoresistance in polycrystalline manganites, Phys. Rev. B 60, 73287334 (1999).

[3] L. Balcells, J. Fontcuberta, B. Martinez, and X. Obradors, High-field magnetoresistance at inter- faces in manganese perovskites, Phys. Rev. B 58, R14697-R146700 (1998).

[4] R. Gross, L. Alff, B. Buechner, B.H. Freitag, C. Hoefener, J. Klein, Y. Lu, W. Mader, J.B. Philipp, M.S.R. Rao, P. Reutler, S. Ritter, S. Thienhaus, S. Uhlenbruck, and B. Wiedenhorst, Physics of grain boundaries in the colossal magnetoresistance manganites, J. Magn. Magn. Mater. 211, 150-159 (2000).

[5] S. Ju, K.W. Yu, and Z.Y. Li, Spatially inhomogeneous transport in phase separated polycrystalline manganites, Phys. Rev B 71, 224401-1-8 (2005).

[6] N. Furukawa, Anomalous shift of chemical potential in the double-exchange systems, J. Phys. Soc. Jpn. 66, 2523-2524 (1997).

[7] M. Viret, L. Ranno, and J.M.D. Coey, Magnetic localization in mixed-valence manganites, Phys. Rev. B 55, 8067-8070 (1997).

[8] J.G. Simmons, Generalized formula for the electric tunnel effect between similar electrodes separated by a thin insulating film, J. Appl. Phys. 34, 1793-1803 (1963).

[9] M. Mansipuram, The Physical Principles of MagnetoOptical Recording (Cambridge University Press, 1995).

[10] H.S. Wang, Q. Li, K. Liu, and C.L. Chien, Low field magnetoresistance anisotropy in ultrathin $\mathrm{Pr}_{0.67} \mathrm{Sr}_{0.33} \mathrm{MnO}_{3}$ films grown on different substrates, Appl. Phys. Lett. 74, 2112-2114 (1999).

[11] G. Herrantz, M. Berkowski, E. Jedrika, M. Wojcik, F. Sanchez, M. Bibes, and J. Fontcuberta, Charge localization in nanometric $\mathrm{La}_{2 / 3} \mathrm{Ca}_{1 / 3} \mathrm{MnO}_{3}$ thin films grown on nearly matching substrates, J. Appl. Phys. 93, 8065-8067 (2003).

[12] S. Balevičius, P. Cimmperman, V. Petrauskas, V. Stankevič, E.E. Tornau, N. Žurauskienè, A. Abrutis, V. Plaušinaitienè, M. Sawicki, T. Dietl, and M. Aleszkiewicz, Two-phase structure of ultra-thin $\mathrm{La}-\mathrm{Sr}-\mathrm{MnO}$ films, accepted for publication in Thin Solid Films. 


\title{
TARPGRANULINĖS VARŽOS MODELIAVIMAS PLONUOSE LANTANO MANGANITU SLUOKSNIUOSE
}

\author{
V. Petrauskas, E.E. Tornau \\ Puslaidininkiu fizikos institutas, Vilnius, Lietuva
}

\section{Santrauka}

Feromagnetinès medžiagos, lantano manganitai, pasižymi vadinamaja milžiniška (colossal) magnetovarža. Pateikti du modeliai, skirti skaičiuoti varžai $R$ tarp feromagnetiniu granulių lantano manganituose. Taikoma fenomenologinè formulè, siejanti varžą, apskaičiuotą krūvininkui tuneliuojant per stačiakampi barjerą, ir sistemos įmagnetejjimą. Granuliu i̇magnetejjimas skaičiuojamas vidutinio lauko metodu.

Pirmasis modelis yra nuosekliai sujungtų feromagnetinių plokštumų (granulių) sistema, imituojanti polikristalinį lantano manganitą. Keičiant magnetines plokštumas nemagnetinėmis ar silpnai magnetinèmis, fiksuojama, kaip pasikeis visos sistemos varža ir magnetovarža. Nustatyta, kad (a) ne įmagnetejimas, o įmagnetejjimo skirtumas tarp kaimyninių granuliu yra esminis faktorius, varžos priklausomybeje nuo temperatūros $R(T)$ lemiantis varžos smailę; (b) $R(T)$ smailè gaunama tik tada, kai medžiaga tarp feromagnetinių granulių taip pat yra bent silpnas (t. y., žemos Kiuri temperatūros) feromagnetikas; (c) granulių skaičiaus didejjimas mažina varžą, bet nekeičia varžos maksimumo $T_{\mathrm{m}}$ padèties temperatūros skalejje.

Antrasis modelis skirtas plonų polikristalinių ir epitaksinių lantano manganitų sluoksnių varžai skaičiuoti. Tai yra dviejų fazių su skirtingomis feromagnetinèmis savybèmis modelis, nes tokie sluoksniai visada turi labiau , itemptas“ plokštumas arčiau padèklo (daug fazès 1 , jos koncentracija $c_{1} \gg c_{2}$ ) ir tolimesnes plokštumas, kuriu savybès yra artimesnès trimatès medžiagos savybèms (daug fazės $2, c_{2} \gg c_{1}$ ). Kiekviena plokštuma yra abiejų feromagnetinių fazių su skirtingais fazių svoriais ir skirtingais įmagnetėjimais mišinys. Jeigu kiekviena plokštuma būtų įsivaizduojama kaip varža, o varža skaičiuojama kaip faziu imagnetejjimų skirtumas, kaip pirmame modelyje, būtų gaunama lygiagrečiai sujungtų varžų sistema, iš esmès tinkama plonų lantano manganitų savitajai varžai ir magnetovaržai modeliuoti. Tokiai sistemai buvo parinkti parametrai ir gautas geras sutapimas su eksperimentiniais duomenimis, t. y., nustatyta, kad, storejjant sluoksniui, varžos smailè mažejja ir $R(T)$ priklausomybèje pasislenka link aukštesnių temperatūros verčių. 